ISSN: 2288-2766 C 2018 EABEA. http://eajbe.jams.or.kr doi: http://dx.doi.org/10.20498/eajbe.2020.8.3.1

\title{
Global Development Strategy of Korean Marine (Leisure) Sports Industry Using SWOT / AHP Method*
}

\author{
Jin Shou XU' ${ }^{1}$, Suwan KIM², Chunsu LEE ${ }^{3}$ \\ 1 First Author Professor, College of Physical Education and Health, East China Normal University, Shanghai, China \\ E-mail: sxjin@tyxx.ecnu.edu.cn \\ 2 co-Author Professor, Department of Arabic Interpretation and Translation, Hankuk University of Foreign \\ Studies, Korea \\ E-mail: suwan@hufs.ac.kr \\ 3 Corresponding Author Professor, College of Business Administration, Pu-Kyong National University, Korea \\ E-mail: chunsu.lee@gmail.com
}

Received: 13 August 2020. Revised: 08 September 2020. Accepted: 10 September 2020

\begin{abstract}
Purpose - Identify the priorities of important factors through SWOT/AHP analysis method for vitalization of global marine sports in Korea. Through this, we will identify prerequisites and strategies for Korean marine sports to become a global powerhouse, including revitalizing the Korean Wave for Chinese consumers. It also revitalizes global competitiveness and draws policy implications.

Research design and methodology - Through interviews with experts and literature data, elements of important opportunities, threats, strengths and weaknesses of marine sports are summarized. Based on this SWOT, the AHP technique is applied to determine which is first and what is important between the factors that save opportunities and increase strengths, and measures to cope with threats and factors that complement weaknesses. Through this, the priority factor of experts suggests a plan for activating strategic marine sports.

Results - First, the current status of marine sports in Korea and the perception of consumers are grasped through current data and literature research. Sub-elements are derived based on the theoretical literature on SWOT elements and opinions of experts. Prioritization is identified based on the AHP questionnaire of Korean experts.

Conclusions - The strategy was derived through SWOT/AHP analysis, and the following implications were obtained. Regionally, Busan is psychologically and geographically adjacent to China and Japan. It is also an area where human exchanges are actively taking place along with the volume of imports and exports. Due to the increase in China's marine sports industry and population, it is necessary to expand the scope of Korea to marine sports beyond cosmetics, dramas, movies, and Korean waves (Hallyu) stars.
\end{abstract}

Keywords: Korean Marine Sports Industry, SWOT, Development Strategy, AHP Method

JEL Classification Code: D04, F14, I00.

\footnotetext{
* Thanks to Dr. Sangha Lee of Pusan National University for advising AHP data analysis. Also, Thanks to AHP survey respondents.

(C) Copyright: The Author(s)

This is an Open Access article distributed under the terms of the Creative Commons Attribution Non-Commercial License (http://Creativecommons.org/licenses/by-nc/4.0/) which permits unrestricted noncommercial use, distribution, and reproduction in any medium, provided the original work is properly cited.
} 


\section{Introduction}

Sports for considering ecological factors such as well-being and green life are in the spotlight. In particular, marine sports are acting as a strategically important factor through synergy such as tourism and leisure. In order to develop and utilize the resources of a particular coastal area, there is a limit to the development only for tourism purposes. Here, there are many attempts to develop tourism and leisure together through various techniques such as storytelling. However, in particular, systematic analysis and attempts to activate tourism and leisure sports through marine sports are insufficient. In this respect, it is necessary to analyze the opportunities and threats, strengths and weaknesses by understanding the external and internal environments of marine sports. In particular, it is necessary to first grasp the important strategic considerations considered by marine sports academia and experts

Marine leisure tourism is affecting the national economy, industry and welfare in various aspects. Especially in relation to marine sports, it is developing into an action that satisfies the needs and desires of consumers. Marine leisure tourism is defined as tourism activities in the sea and coastal areas and marine leisure and sports activities (Article 28 of the Framework Act on Marine Fisheries Development) to improve the health, leisure and emotional life of the people.

First of all, if we look at the characteristics of marine leisure tourism, the characteristic of marine leisure tourism is seasonality. Due to the high dependence on the marine environment (tidal wave, tide, wind) and sensitive to weather changes, there are differences in the types of marine leisure sports that can be enjoyed depending on the season. Most marine leisure tours are available in summer, but other activities are restricted. In terms of economy, the cost of tourism, such as the concentration of demand in summer, the need to purchase and rent early education and leisure and safety equipment is high cost compared to inland tourism, so the economic benefits is low. In terms of safety, it is important to secure safety to cope with changing environments such as waves, tsunamis, and tidal currents as activities conducted in the sea and offshore.

The number of domestic marine leisure tourism users in Korea recorded 5.8 million in 2017, and is expanding to various fields such as surfing $(100,000)$, underwater leisure $(1,800,000)$, and canoeing and kayak $(15,000)$. Statistics Korea), Korea Institute of Oceans and Fisheries, 2017 Ocean Economy, 2018 Annual Economic Report on EU blue economy). The domestic marine industry was about 183 trillion won in 2016.

The annual total expenditure in the marine leisure tourism sector is estimated at 23 trillion won, the effect of inducing total production is 42.2 trillion won, and the effect of inducing added value is 16.6 trillion won (KMI, 2015). In 2016, the number of marine leisure tourism (excluding marine industry statistics, food and lodging business) increased to $974(2.1 \% \uparrow)$, sales of 460 billion won $(23.3 \% \uparrow)$, and 2,697 employees $(17.8 \% \uparrow)$ from the previous year (Korean marine industry statistics survey, fishery survey).

Considering the characteristics and development statistics of marine leisure sports, it is necessary to systematically analyze Korea's internal strengths and weaknesses, and external opportunities and threats. In particular, a strategy is needed to save strengths and compensate for weaknesses. In addition, it is necessary to derive various SWOT strategies that can save opportunities and eliminate threats. In this study, through SWOT analysis and AHP, we find important priority variables and derive marketing strategies that can develop the Korean marine sports industry. This will help develop policies favored by governments, global companies and consumers.

\section{Literature Review}

\subsection{Current status of the Korean marine sports industry}

The meaning of marine leisure sports refers to all leisure sports activities in the sea, such as sea areas and coasts. It can also be classified according to whether a power device is used or not. When the power device is not used, there are canoe, kayak, skin scuba, snorkeling, windsurfing, and surfing. In the case of using power equipment, there are boating, yacht, boat, banana boat, peanut boat, speed boat, power boat, flying boat, windsurfing, wakeboard, jet ski, etc.

Marine leisure sports related to industries include infrastructure industry (marina, breakwater, port, fishing port, fisherina, marine leisure sports complex/complex, resort, etc.), equipment industry (boats, yachts, various equipment, electronic equipment, etc.), and tourism service industry (marine tourism, education, boat show, racing, rental, etc.).

In this study, as the meaning of marine leisure sports, it is defined as a concept that includes both the general public and experts by expanding to marine sports. The number of people enjoying marine leisure is rapidly increasing due to the increase in income and the expansion of leisure time, such as working five days a week. Korea, where three sides 
of the country is the sea, has a natural environment that is good for enjoying marine leisure, including a coastline close to $15,000 \mathrm{~km}$, more than 3,300 islands, and 270 beaches.

The number of people experiencing marine sports in Korea increased 31.4\% from 723,000 in 2013 to 950,000 in 2017. The surfing population, which is popular with young people, has increased from 40,000 in 2014 to 200,000, which is fivefold in 2017. In the case of advanced countries, when the national income reaches the era of 30,000 dollars, the number of people enjoying marine leisure rapidly increases and opens the era of popularization.

Korea also has a rapid increase in the marine leisure population, but it is still far behind the level of popularization compared to advanced countries. As of 2018, the number of domestically registered marine leisure vessels was 22,131 ships in the United States (13.80 million), Canada (8.6 million), Norway (800,000), Sweden (754,300), and Japan. $(288,000,600$ vessels). The Korean government and local governments are expanding facilities and operating various experience programs to develop marine leisure as a future industry. In the case of Korea, considering the rich natural infrastructure such as a coastline of 13,500 km, more than 3,000 islands, and 350 beaches, the growth potential of the marine leisure industry is very high. In the case of the yacht and boat industry, which is the core of the marine leisure industry. It is the result of the marina industry, which can create an employment effect of 30,000 people and added value of 2.6 trillion won by 2020 . The Korean government plans to build 46 marina ports by 2019 and expand the marina berth, currently only 1,500 ships, to 6,000 ships. The number of global tourists increased from 690 million in 2000 to 990 million in 2011, and is expected to increase to 1.6 billion in 2020 (source, Yonhap News, 2019.08.22).

In Korea, water leisure sports such as water skiing and wakeboarding have been popular in Gapyeong in recent years. With the trend of water leisure sports, interest in marine leisure sports is also increasing. Marine leisure sports are sports that show off new experiences through social media, and are well suited to the psychology of modern people who seek experiences. The government is also investing in marine sports considering the possibility of developing and creating jobs. Therefore, the future market outlook is very bright (Benrie, 2019).

The number of overseas Chinese travelers has been growing positively every year. According to the China Tourism Research Institute (CTA), the number of overseas Chinese tourists surpassed 100 million in 2015 with a growth rate of $9.3 \%$ compared to the previous year. In 2018, it reached 144.72 million, an increase of $14.7 \%$ from the previous year. Since 2015, when the number of overseas travelers surpassed 100 million for the first time, it has been accounting for about $10 \%$ of the number of global travelers, and in 2018 it reached $10.7 \%$ of the number of international travelers based on double-digit growth. One in ten overseas travelers worldwide is Chinese.

According to the World Tourism Organization, Chinese people spent 250 billion dollars (about 290 trillion won) annually on overseas travel between 2015 and 2017, accounting for $20 \%$ of the world's tourist destinations. In 2018, it increased 7\% year-on-year to $\$ 277.3$ billion (about 321 trillion won), accounting for 19.2\% of global tourism spending (Lee, 2020).

\subsection{Literature Review}

Park and Kim (2002) researched and analyzed the marketing aspect of marine leisure sports and suggested an effective marketing strategy through SWOT analysis to effectively satisfy the needs and desires of consumers. Lim (2019) emphasizes the selection of a safe place for expansion of marine sports facilities, harmonious design of land and sea spaces, and expertise, as a way to develop the marine sports industry in Korea. Second, the development of marine sports equipment includes fostering specialized companies, improving systems, and holding specialized exhibitions. Finally, in marine sports service, it was suggested to cultivate professional manpower, organize regular curriculum in schools, strengthen water safety education, develop and distribute various marine sports events, develop specialized marine sports tourism products, and develop facilities-centered seasonality overcome programs.

Heung, Kim, and Seo (2009) suggested a plan to build a human infrastructure for training experts related to marine sports. Yong Bum Park (2000) studied a plan to activate sports tourism for the development of local communities. Hwang (2018) tried to understand the effect of leisure policy on the use of leisure, and assumed that the leisure policy had an effect on the satisfaction of private leisure facilities and the satisfaction of public leisure facilities. I figured out whether it was the effect.

Rui, et al. (2019) discussed various aspects of familiarity with the marine and how familiarity with the marine (sea) is perceived. And this study has identified the marine (sea) tourism resources, marine ecology, and the cognitive/emotional situations of consumers to demand that should be developed practically and widely. Lee, et al. (2017) used social media big data to examine the trends in the perception of marine sports. Park (2017) collected and analyzed the meaning of social big data (Twitter, blog) related to marine sports such as Wonder Surfing, Yachting, Jet Ski, Skin Scuba, and Sea Fishing.

Based on the preceding studies, the strengths and weaknesses of the Korean marine sports industry, as well as the factors related to opportunities and threats can be summarized according to important matters as follows. First, the 
strengths of Korea in marine sports in the internal environment are as follows. Communication through social networks such as blogs, Twitter, and YouTube has exploded (S1). Through this, consumers can learn professional knowledge and access to various information. Korean companies traditionally have the ability to change, which is suited for the global environment and achieve company-wide results through innovative differentiation within the company (S2). The continued expansion of the wellness tourism market due to the continuous increase in social interest in health and happiness gives an opportunity to achieve the development of industries related to marine sports (S3). Since Korea has three sides of the sea in its land, it is possible to conduct various marine leisure tourism activities specialized locally in various oceans and inland areas (S4). However, there is a problem of overcoming obsolete or undeveloped marine facilities in inverse proportion to the rapid increase in consumers' perception and experience of marine sports (W1). Compared to overseas, it is necessary to establish a systematic and systematic basis for training specialized educational institutions and manpower for marine education (W2). Since Korea has four seasons, the temperature difference between summer and winter is large, so it is necessary to carefully prepare measures for seasonal off-season for marine sports (W3). It is necessary to cultivate global marketing capabilities by actively developing the current insufficient infrastructure and cultural core Korean Wave contents by developing various contents (W4).

Looking at opportunities in terms of external environment, global economic growth and increase in income increase consumers' interest in marine sports, giving various consumers an opportunity to participate (O1). The initiation of domestic KTX and inland aviation and the development of communication networks gave consumers many opportunities for maritime access and information acquisition $(\mathrm{O} 2)$. The 5-day system was settled, well-being life increased, and opportunities to spend family time increased, increasing the time to use it for marine sports (O3). Paradoxically, due to climate warming, Korea has an opportunity to increase the number of sports and experiential tourism related to marine activities as the annual average temperature rises and the summer period increases (O4).

However, compared to these opportunity factors, domestic legal and institutional aspects of marine sports are insufficient. Therefore, it is necessary to improve global legal and institutional regulations to the level of advanced countries (T1). The rapid economic growth of emerging powerhouses and the emergence of competing companies are providing fierce battles over global competition leadership in the Korean sports industry, so it is necessary to secure the leadership by establishing active investment and marketing strategies (T2). . There is a very shortage of specialized educational institutions, curriculums, and institutions that cultivate experts related to domestic marine sports. Therefore, efforts of the government and universities are required to educate and nurture experts on various marine sports systematically (T3). Due to aging and declining natural population, local population change is a big threat. In particular, there is a need for policy support to overcome the problem of migrating young people to urban areas and to prepare for the commonalization of coastal areas along the coast, investments in coastal areas for corresponding jobs, and a characteristic activation plan (T4).

SWOT/AHP analysis is an analysis method that can complement each other's shortcomings and derive strategies by combining qualitative SWOT analysis and quantitative AHP analysis. Kurttila, et al. (2000) and Kangas, et al. (2001) evaluated that SWOT analysis had limitations such as difficulty in quantitative measurement, lack of objectivity in factor generation, and lack of prioritization. In order to overcome this limitation, SWOT/AHP analysis, which combines SWOT analysis with AHP analysis, appeared.

The Analytical Hierarchy Process (AHP) technique is used as a decision-making tool by researchers in various fields, and is often used in combination with other methodologies to overcome the limitations of the AHP technique. The SWOT/AHP analysis method, which combines SWOT analysis and AHP analysis, has been applied since 2000, which is relatively recent, and is widely used (Ho, 2008). Representative studies include existing studies on the hydrogen energy industry, tourism industry, and aviation logistics industry. Specifically, a study of "SWOT/AHP Analysis for Reinforcing Brand Competitiveness in Gyeongju Tourism City" by Seol, et al. (2011) was conducted. In addition, Kim and Chung (2012) described the SWOT factors from literature studies in "Development Strategy of Korean Air Logistics Industry Using SWOT/AHP Method" to find implications for the development strategy of Korean air logistics industry. It was organized, and representative SWOT factors were derived and layered.

Jin, et al. (2020) analyzed the general status of the hydrogen industry, reviewed overseas cases, and analyzed SWOT/AHP. The internal capabilities related to the hydrogen industry were analyzed and the importance of factors that could affect the development of the hydrogen industry was calculated. Based on the preceding research, $<$ Table $1>$ Korean marine sports SWOT/AHP factors summarize the elements of this study. 
Table 1: Korean marine sports SWOT/AHP factors

\begin{tabular}{|c|c|c|c|}
\hline Top goal & Tier 1 factor & Tier 2 factor & Prior research \\
\hline \multirow{16}{*}{$\begin{array}{l}\text { Strengthening } \\
\text { global } \\
\text { competitiveness } \\
\text { of Korean } \\
\text { marine sports }\end{array}$} & \multirow{4}{*}{$\begin{array}{c}\text { Strength } \\
\text { development } \\
\text { (S) }\end{array}$} & $\begin{array}{l}\text { Increasing communication through social } \\
\text { networks(S1) }\end{array}$ & \multirow{4}{*}{$\begin{array}{c}\text { Park, M. K. \&, Kim, S. K. } \\
(2002) \\
\text { Materials for joint } \\
\text { meetings of government- } \\
\text { related ministries on } \\
\text { measures to revitalize } \\
\text { marine leisure tourism } \\
(2019) \\
\text { Lim, K. H. (2019) } \\
\text { Park, T. S. (2017) }\end{array}$} \\
\hline & & $\begin{array}{l}\text { Ability to change according to the global } \\
\text { environment(S2) }\end{array}$ & \\
\hline & & $\begin{array}{c}\text { Continued expansion of wellness tourism } \\
\text { market(S3) }\end{array}$ & \\
\hline & & $\begin{array}{l}\text { Various marine leisure tourism activities are } \\
\text { possible(S4) }\end{array}$ & \\
\hline & \multirow{4}{*}{$\begin{array}{l}\text { Overcoming } \\
\text { weakness } \\
\text { (W) }\end{array}$} & Overcoming outdated facilities(W1) & \multirow{4}{*}{$\begin{array}{c}\text { Park, M. K. \&, Kim, S. K. } \\
\text { (2002) } \\
\text { Heung, et al. (2009) } \\
\text { Materials for joint } \\
\text { meetings of government- } \\
\text { related ministries on } \\
\text { measures to revitalize } \\
\text { marine leisure tourism } \\
(2019) \\
\text { Lim, K. H. }(2019) \\
\text { Park, Y. B. }(2000)\end{array}$} \\
\hline & & $\begin{array}{c}\text { Training specialized educational institutions } \\
\text { and manpower(W2) }\end{array}$ & \\
\hline & & $\begin{array}{l}\text { Prepare for seasonal off-season } \\
\text { countermeasures(W3) }\end{array}$ & \\
\hline & & $\begin{array}{l}\text { Cultivating global marketing capabilities } \\
\text { (development of various contents) (W4) }\end{array}$ & \\
\hline & \multirow{4}{*}{$\begin{array}{l}\text { Opportunity } \\
\text { development } \\
\text { (O) }\end{array}$} & $\begin{array}{c}\text { Increased interest in marine sports and } \\
\text { income }(\mathrm{O} 1)\end{array}$ & \multirow{4}{*}{$\begin{array}{c}\text { Park, M. K. \&, Kim, S. K. } \\
\text { (2002) } \\
\text { Materials for joint } \\
\text { meetings of government- } \\
\text { related ministries on } \\
\text { measures to revitalize } \\
\text { marine leisure tourism } \\
\text { (2019) } \\
\text { Hwang, H. S. (2018) } \\
\text { Lim, K. H. (2019) }\end{array}$} \\
\hline & & $\begin{array}{c}\text { Transportation and communication } \\
\text { development }(\mathrm{O} 2)\end{array}$ & \\
\hline & & Increase in available leisure time(O3) & \\
\hline & & $\begin{array}{l}\text { Increased ocean temperature and extended } \\
\text { period (increased number of hot days due to } \\
\text { climate change; increased experience } \\
\text { tourism) (O4) }\end{array}$ & \\
\hline & \multirow{4}{*}{$\begin{array}{l}\text { Overcoming } \\
\text { Threats } \\
\text { (T) }\end{array}$} & $\begin{array}{c}\text { Global legal and institutional regulation } \\
\text { improvement(T1) }\end{array}$ & \multirow{4}{*}{$\begin{array}{c}\text { Park, M. K. \&, Kim, S. K. } \\
(2002) \\
\text { Materials for joint } \\
\text { meetings of government- } \\
\text { related ministries on } \\
\text { measures to revitalize } \\
\text { marine leisure tourism } \\
(2019) \\
\text { Lim, K. H. (2019) }\end{array}$} \\
\hline & & Securing global competition(T2) & \\
\hline & & Training of global experts(T3) & \\
\hline & & $\begin{array}{l}\text { Prevent coastal communalization due to a } \\
\text { decrease in local population(T4) }\end{array}$ & \\
\hline
\end{tabular}




\section{Methodology}

\subsection{Process}

The biggest advantage of the AHP method is that it can calculate the importance of a small number of samples through a scientific method. Therefore, the AHP analysis method has the advantage of being able to conduct research regardless of the number of samples by targeting a small number of experts. In addition, the AHP analysis method reflects qualitative factors rationally and makes it possible to convincingly derive the importance comparison with quantitative factors, and by calculating the CI (consistency index), the criteria for checking and improving the logical consistency of decision makers are suggested (Lee, 2010). In the first step, the most important step in the application of AHP, the decision analyst stratifies several interrelated decisions. The most comprehensive purpose of decisionmaking is placed at the top of the hierarchy, and the following hierarchies are composed of various factors to influence the purpose of decision-making (Cho, et al., 2005).

Subsequently, in step 2, in order to determine how important a specific evaluation criterion at the middle level of the hierarchy and the evaluation attributes at a lower level are relatively important, $\mathrm{N}$ respondents at each level are pairwise compared the evaluation criteria and all evaluation attributes (pairwise comparison).

In step 3, the pairwise comparison matrix obtained through the pairwise comparison from $\mathrm{N}$ respondents is synthesized to obtain a composite pairwise comparison matrix that can represent the opinions of the entire group.

In step 4, the consistency of responses is reviewed after obtaining weights, which are the relative importance of individual evaluation criteria and evaluation attributes from the comprehensive pairwise comparison matrix. To this end, in this study, the eigenvector corresponding to the maximum eigenvalue of the comprehensive binary comparison matrix was derived as the relative weight of individual evaluation criteria and evaluation attributes using the eigenvector method (Saaty, 1980). The consistency test of the comprehensive pairwise comparison matrix is measured as a consistency ratio (CR), which is a value obtained by dividing the consistency index (CI) by a random index (RI) obtained from empirical data as follows (Jeong \& Hwang, 2008).

In general, when the value of the consistency ratio (CR) is less than 0.1 , the judgment of the group as a whole is considered to be consistent (Saaty \& Kearns, 1985). On the other hand, Rho, et al. (1996) argued that when targeting people with low understanding of the AHP technique, the CR value up to 0.2 or less can be accepted as acceptable. In addition, the process of multiplying the weights of the evaluation criteria at the upper level calculated through the eigenvector method with the weights of the evaluation attributes at the lower level is sequentially repeated from the highest level to the lowest level.

Excel 2010 and Expert Choice 2000 programs were used as tools for AHP analysis performed in this study. As in the study of Jin, et al. (2020), the detailed attribute factors were selected by deriving the factors of Strength, Weakness, Opportunity, and Threat of the Korean marine sports industry. So, the SWOT-Matrix was created after selecting a total of 16 detailed factors through literature and expert opinions.

\subsection{Sample and Model}

The subjects of the survey were Korean marine sports experts and doctors and $\mathrm{Ph}$. D. Candidates who are experts in the academic world. The questionnaire was composed of each detailed factor on a scale of $9(-,+)$, and was composed of items for calculating the importance of the first-tier factors and the second-tier factors. The survey was distributed through e-mail. A total of 34 questionnaires were collected, and 27 questionnaires with a CR value of 0.2 or less and an acceptable level of consistency were used for analysis.

\section{Results}

\subsection{Demographic characteristics}

In the Table 2, demographically, the number of years worked for 15 years or more was the highest at $33.3 \%$, and the main had more than 10 years of experience. In addition, there was at $29.7 \%$ of the responses from the associate professor class. By occupation and field, 96.3\% were academic experts. 
Table 2: Demographic characteristics

\begin{tabular}{|c|c|c|c|}
\hline \multicolumn{2}{|c|}{ Division } & Frequency & $\%$ \\
\hline \multirow{6}{*}{ Working years } & 1 year or less & 1 & 3.7 \\
\hline & Less than 5 years & 3 & 11.1 \\
\hline & 10 years or less & 7 & 25.9 \\
\hline & 15 years or less & 7 & 25.9 \\
\hline & 15 years or more & 9 & 33.3 \\
\hline & Total & 27 & 100.0 \\
\hline \multirow{6}{*}{ Position } & Marine sports expert & 1 & 3.7 \\
\hline & Assistant Professor & 2 & 7.4 \\
\hline & Associate Professor & 8 & 29.6 \\
\hline & Professor & 2 & 7.4 \\
\hline & Etc. & 14 & 51.9 \\
\hline & Total & 27 & 100.0 \\
\hline \multirow{3}{*}{$\begin{array}{l}\text { Occupation/ } \\
\text { Related field }\end{array}$} & Practical Expert & 1 & 3.7 \\
\hline & Academic experts & 26 & 96.3 \\
\hline & Total & 27 & 100.0 \\
\hline
\end{tabular}

\subsection{First-tier factor evaluation results}

As shown in Table 3, the evaluation items of the first-tier factor consisted of four items: strength development, weakness overcoming, opportunity development, and overcoming threats, and the importance (weight) was derived. The importance of the four items of the first-tier factor was in the order of opportunity development $(0.403)$, strength development (0.352), threat overcoming (0.127), and weakness overcoming (0.118), and the CR value was 0.015 , indicating the consistency of the survey. And it turns out to be consistent.

Table 3: Results of the importance of Tier 1 factors

\begin{tabular}{|c|c|c|c|c|}
\hline Division & $\begin{array}{c}\text { Strength } \\
\text { Development (S) }\end{array}$ & $\begin{array}{c}\text { Weakness } \\
\text { Overcoming (W) }\end{array}$ & $\begin{array}{c}\text { Opportunity } \\
\text { Development (O) }\end{array}$ & $\begin{array}{c}\text { Overcoming } \\
\text { Threats (T) }\end{array}$ \\
\hline strength development (S) & 1.000 & 3.897 & 0.733 & 2.572 \\
\hline weakness overcoming (W) & 0.257 & 1.000 & 0.301 & 1.125 \\
\hline opportunity development (O) & 1.365 & 3.222 & 1.000 & 2.824 \\
\hline overcoming threats (T) & 0.389 & 0.889 & 0.354 & 1.000 \\
\hline the importance (weight) & 0.352 & 0.118 & 0.403 & 0.127 \\
\hline & \multicolumn{3}{|c|}{$\lambda \max =4.040 \mathrm{CI}=0.013 \mathrm{CR}=0.015$} \\
\hline
\end{tabular}

\subsection{2nd-tier factor evaluation result}

As shown in Table 4, the evaluation items for strength development are: Increasing communication through social networks (S1), the ability to change according to the global environment (S2), wellness, and continued expansion of the tourism market (S3), and various marine leisure activities. The importance was derived by configuring the evaluation items of possible tourism activities (S4). The CR value was 0.002 , and it was evaluated that the consistency of the survey. 
Table 4: Results of the importance of developing strength marine sports in Korea

\begin{tabular}{|c|c|c|c|c|}
\hline Division & $\begin{array}{c}\text { Increasing } \\
\text { communication } \\
\text { through social } \\
\text { networks (S1) }\end{array}$ & $\begin{array}{c}\text { The ability to } \\
\text { change according } \\
\text { to the global } \\
\text { environment (S2) }\end{array}$ & $\begin{array}{c}\text { Wellness, and } \\
\text { continued expansion } \\
\text { of the tourism market } \\
\text { (S3) }\end{array}$ & $\begin{array}{c}\text { Various marine } \\
\text { leisure activities } \\
\text { (S4) }\end{array}$ \\
\hline $\begin{array}{c}\text { Increasing } \\
\text { communication through } \\
\text { social networks (S1) }\end{array}$ & 1.000 & 0.596 & 0.529 & 0.662 \\
\hline $\begin{array}{c}\text { the ability to change } \\
\text { according to the global } \\
\text { environment (S2) }\end{array}$ & 1.678 & 1.000 & 0.917 & 1.061 \\
\hline $\begin{array}{c}\text { wellness, and continued } \\
\text { expansion of the } \\
\text { tourism market (S3) }\end{array}$ & 1.889 & 1.090 & 1.000 & 1.000 \\
\hline $\begin{array}{c}\text { various marine leisure } \\
\text { activities (S4) }\end{array}$ & 1.510 & 1.111 & 0.943 & 0.274 \\
\hline $\begin{array}{c}\text { the importance } \\
\text { (weight) }\end{array}$ & 0.165 & 0.265 & 0.296 & \\
\hline \multicolumn{2}{|c|}{} & $\lambda \max =4.005 \mathrm{CI}=0.002 \mathrm{CR}=0.002$ & \\
\hline
\end{tabular}

The evaluation items for overcoming weakness are shown in Table 5. The importance was derived from evaluation items consisting of overcoming poor facilities (W1), training of specialized educational institutions and manpower (W2), preparation for seasonal off-season (W3), and cultivation of global marketing capabilities (W4). The CR value was 0.001 , and it was evaluated that the consistency of the questionnaire was secured.

Table 5: Results of the importance of overcoming weaknesses in Korean marine sports

\begin{tabular}{|c|c|c|c|c|}
\hline Division & $\begin{array}{l}\text { Overcoming } \\
\text { poor facilities } \\
\text { (W1) }\end{array}$ & $\begin{array}{l}\text { training of specialized } \\
\text { educational institutions } \\
\text { and manpower (W2) }\end{array}$ & $\begin{array}{l}\text { preparation for } \\
\text { seasonal off- } \\
\text { season }(\mathbf{W} 3)\end{array}$ & $\begin{array}{c}\text { cultivation of } \\
\text { global marketing } \\
\text { capabilities (W4) }\end{array}$ \\
\hline $\begin{array}{l}\text { overcoming poor } \\
\text { facilities (W1) }\end{array}$ & 1.000 & 1.691 & 1.985 & 1.946 \\
\hline $\begin{array}{l}\text { training of specialized } \\
\text { educational institutions } \\
\text { and manpower (W2) }\end{array}$ & 0.591 & 1.000 & 1.374 & 1.255 \\
\hline $\begin{array}{c}\text { preparation for seasonal } \\
\text { off-season (W3) }\end{array}$ & 0.504 & 0.728 & 1.000 & 0.921 \\
\hline $\begin{array}{l}\text { cultivation of global } \\
\text { marketing capabilities } \\
\text { (W4) }\end{array}$ & 0.514 & 0.797 & 1.086 & 1.000 \\
\hline \multirow[t]{2}{*}{ the importance (weight) } & 0.382 & 0.240 & 0.182 & 0.195 \\
\hline & \multicolumn{4}{|c|}{$\lambda \max =4.002 \mathrm{CI}=0.001 \mathrm{CR}=0.001$} \\
\hline
\end{tabular}

The evaluation items of opportunity development are shown in Table 6 . The importance was derived by consisting of the evaluation items of interest in marine sports and income increase (O1), development of transportation and communication $(\mathrm{O} 2)$, increase of available leisure time $(\mathrm{O} 3)$, increase in the appropriate water temperature for marine activities and extension of period (O4). The CR value was 0.003 , and it was evaluated that the consistency of the questionnaire was secured. 
Table 6: Results of Importance of Korean Ocean Sports Opportunity Development

\begin{tabular}{|c|c|c|c|c|}
\hline Division & $\begin{array}{c}\text { Marine sports } \\
\text { and income } \\
\text { increase (O1) }\end{array}$ & $\begin{array}{c}\text { Development of } \\
\text { transportation and } \\
\text { communication (O2) }\end{array}$ & $\begin{array}{c}\text { Increase of } \\
\text { available leisure } \\
\text { time (O3) }\end{array}$ & $\begin{array}{c}\text { Increase in the } \\
\text { appropriate water } \\
\text { temperature (O4) }\end{array}$ \\
\hline $\begin{array}{c}\text { marine sports and } \\
\text { income increase (O1) }\end{array}$ & 1.000 & 4.347 & 2.449 & 4.453 \\
\hline $\begin{array}{c}\text { development of } \\
\text { transportation and } \\
\text { communication (O2) }\end{array}$ & 0.230 & 1.000 & 0.677 & 1.380 \\
\hline $\begin{array}{c}\text { increase of available } \\
\text { leisure time (O3) }\end{array}$ & 0.408 & 1.477 & 1.000 & 2.125 \\
\hline $\begin{array}{c}\text { increase in the } \\
\text { appropriate water } \\
\text { temperature (O4) }\end{array}$ & 0.225 & 0.725 & 0.471 & 1.000 \\
\hline $\begin{array}{c}\text { the importance } \\
\text { (weight) }\end{array}$ & 0.536 & 0.139 & 0.217 & 0.108 \\
\hline \multicolumn{1}{|c|}{} & $\lambda \max =4.009 \mathrm{CI}=0.003 \mathrm{CR}=0.003$ & \\
\hline
\end{tabular}

The evaluation items for overcoming threats are shown in $<$ Table $7>$. The importance was derived by consisting of evaluation items such as reorganization of global legal and institutional regulations (T1), securing global competition initiative (T2), training of global experts (T3), and prevention of coastal communization due to a decrease in local population (T4). The CR value was 0.016 , and it was evaluated that the consistency of the survey was secured.

Table 7: Results of the importance of overcoming the threat of Korean marine sports

\begin{tabular}{|c|c|c|c|c|}
\hline Division & $\begin{array}{l}\text { Reorganization of } \\
\text { global legal and } \\
\text { institutional } \\
\text { regulations (T1) }\end{array}$ & $\begin{array}{c}\text { Securing global } \\
\text { competition } \\
\text { initiative (T2) }\end{array}$ & $\begin{array}{l}\text { Training of } \\
\text { global experts } \\
\text { (T3) }\end{array}$ & $\begin{array}{c}\text { Prevention of } \\
\text { coastal } \\
\text { communization (T4) }\end{array}$ \\
\hline $\begin{array}{l}\text { reorganization of global } \\
\text { legal and institutional } \\
\text { regulations }(\mathrm{T} 1)\end{array}$ & 1.000 & 1.239 & 0.853 & 1.785 \\
\hline $\begin{array}{c}\text { securing global } \\
\text { competition initiative } \\
\text { (T2) }\end{array}$ & 0.807 & 1.000 & 1.126 & 2.405 \\
\hline $\begin{array}{l}\text { training of global experts } \\
\text { (T3) }\end{array}$ & 1.173 & 0.888 & 1.000 & 2.886 \\
\hline $\begin{array}{l}\text { prevention of coastal } \\
\text { communization (T4) }\end{array}$ & 0.560 & 0.416 & 0.346 & 1.000 \\
\hline \multirow[t]{2}{*}{ the importance (weight) } & 0.277 & 0.287 & 0.310 & 0.126 \\
\hline & \multicolumn{4}{|c|}{$\lambda \max =4.044 \mathrm{CI}=0.015 \mathrm{CR}=0.016$} \\
\hline
\end{tabular}

\subsection{Composite factor evaluation result}

In Table 8, the priority of all SWOT elements can be viewed through composite weights. The strengths (S3, S4, and S2) and opportunity (O1, O3, and O7) factors were included in many important priorities. 
Table 8: Results of comprehensive analysis of importance through composite weight

\begin{tabular}{|c|c|c|c|c|c|c|c|}
\hline $\begin{array}{l}\text { Tier } 1 \\
\text { factor }\end{array}$ & $\mathrm{CR}$ & importance & $\begin{array}{l}\text { Tier } 2 \\
\text { factor }\end{array}$ & $\mathrm{CR}$ & importance & $\begin{array}{l}\text { composite } \\
\text { weight }\end{array}$ & ranking \\
\hline \multirow{4}{*}{$\begin{array}{l}\text { strength } \\
\text { development } \\
\text { (S) }\end{array}$} & \multirow{16}{*}{0.015} & \multirow{4}{*}{0.352} & $\begin{array}{c}\text { Increasing communication } \\
\text { through social networks } \\
(\mathrm{S} 1)\end{array}$ & \multirow{4}{*}{0.002} & 0.165 & 0.058 & 6 \\
\hline & & & $\begin{array}{l}\text { the ability to change } \\
\text { according to the global } \\
\text { environment (S2) }\end{array}$ & & 0.265 & 0.093 & 4 \\
\hline & & & $\begin{array}{l}\text { wellness, and continued } \\
\text { expansion of the tourism } \\
\text { market (S3) }\end{array}$ & & 0.296 & 0.104 & 2 \\
\hline & & & $\begin{array}{l}\text { various marine leisure } \\
\text { activities (S4) }\end{array}$ & & 0.274 & 0.096 & 3 \\
\hline \multirow{4}{*}{$\begin{array}{l}\text { weakness } \\
\text { overcoming } \\
\text { (W) }\end{array}$} & & \multirow{4}{*}{0.118} & $\begin{array}{l}\text { overcoming poor facilities } \\
\text { (W1) }\end{array}$ & \multirow{4}{*}{0.001} & 0.382 & 0.045 & 8 \\
\hline & & & $\begin{array}{l}\text { training of specialized } \\
\text { educational institutions } \\
\text { and manpower (W2) }\end{array}$ & & 0.240 & 0.028 & 13 \\
\hline & & & $\begin{array}{c}\text { preparation for seasonal } \\
\text { off-season (W3) }\end{array}$ & & 0.182 & 0.021 & 15 \\
\hline & & & $\begin{array}{l}\text { cultivation of global } \\
\text { marketing capabilities } \\
\text { (W4) }\end{array}$ & & 0.195 & 0.023 & 14 \\
\hline \multirow{4}{*}{$\begin{array}{l}\text { opportunity } \\
\text { development } \\
\text { (O) }\end{array}$} & & \multirow{4}{*}{0.403} & $\begin{array}{l}\text { marine sports and income } \\
\text { increase }(\mathrm{O} 1)\end{array}$ & \multirow{4}{*}{0.003} & 0.536 & 0.216 & 1 \\
\hline & & & $\begin{array}{c}\text { development of } \\
\text { transportation and } \\
\text { communication }(\mathrm{O} 2)\end{array}$ & & 0.139 & 0.056 & 7 \\
\hline & & & $\begin{array}{l}\text { increase of available } \\
\text { leisure time }(\mathrm{O} 3)\end{array}$ & & 0.217 & 0.087 & 5 \\
\hline & & & $\begin{array}{c}\text { increase in the appropriate } \\
\text { water temperature }(\mathrm{O} 4)\end{array}$ & & 0.108 & 0.044 & 9 \\
\hline \multirow{4}{*}{$\begin{array}{l}\text { overcoming } \\
\text { threats }(\mathrm{T})\end{array}$} & & \multirow{4}{*}{0.127} & $\begin{array}{l}\text { reorganization of global } \\
\text { legal and institutional } \\
\text { regulations }(\mathrm{T} 1)\end{array}$ & \multirow{4}{*}{0.016} & 0.277 & 0.035 & 12 \\
\hline & & & $\begin{array}{c}\text { securing global } \\
\text { competition initiative (T2) }\end{array}$ & & 0.287 & 0.036 & 11 \\
\hline & & & $\begin{array}{c}\text { training of global experts } \\
\text { (T3) }\end{array}$ & & 0.310 & 0.039 & 10 \\
\hline & & & $\begin{array}{l}\text { prevention of coastal } \\
\text { communization (T4) }\end{array}$ & & 0.126 & 0.016 & 16 \\
\hline Total & & 1.000 & & & & 1.000 & \\
\hline
\end{tabular}

* Composite weight $=($ Level 1 factor importance $) \times($ Level 2 factor importance $)$ 


\subsection{Derivation of SWOT strategy according to AHP}

In the first-tier analysis of AHP results, it was found that developing opportunities and strengths prioritizes overcoming threats and overcoming weaknesses. As a result of the second-tier priority analysis, as a result of the importance of strength development, the continued expansion of the wellness tourism market (S3) was given priority as a factor in the marine sports field with the highest strength. As a result of the importance of overcoming the weaknesses of marine sports, improving and overcoming poor facilities (W1) was an important priority.

In the results of the importance of opportunity development for marine sports in Korea, the interest in marine sports and an increase in income (O1) were shown as important priority for opportunity development. In the result of the importance of overcoming threats, it was analyzed that the factors of overcoming threats through training of global experts (T3) are the most important. SWOT-Matrix was created as shown in the table below.

Table 9: Strategic Development Direction Matrix

\begin{tabular}{|c|cc|cc|}
\hline & \multicolumn{2}{|c|}{ Opportunity development (O) } & \multicolumn{2}{|c|}{ Weakness overcoming (W) } \\
\hline strength development (S) & S3 O1 & (SO) & (WO) & W1 O1 \\
\hline overcoming threats (T) & S3 T3 & (ST) & (WT) & W1 T3 \\
\hline
\end{tabular}

Therefore, the SWOT strategy according to AHP can be derived as follows. As a SO strategy, it is possible to propose a strategy to use marine sports as an opportunity for interest in marine sports and income increase (O1) by utilizing the internal strengths of the continued expansion of the wellness tourism market (S3).

It is a strategy to overcome threats and revitalize the Korean marine sports market by utilizing the strengths of the continuing expansion of the wellness tourism market (S3) as an ST strategy and fostering global experts (T3). The need to improve and overcome (W1) underdeveloped facilities related to marine sports with the WO strategy is a priority, and this can be utilized by taking advantage of interest in marine sports and opportunities for income increase (O1). WT Strategy It is necessary to cooperate with the industry, the summer and the government departments so that a new strategy can be prepared through training of global experts (T3) to improve and overcome the underdeveloped facilities (W1).

\section{Conclusion}

Based on the empirical results of this study, a developmental market strategy for Korean marine sports was derived. The priorities of SWOT were derived through AHP analysis based on the opinions of experts. In the AHP composite priority analysis, developing opportunities and strengths were analyzed as important in priority. In particular, interest in marine sports and income increase (O1), wellness (S3), continued expansion of the tourism market, various marine leisure tourism activities are possible (S4), and the ability to change in line with the global environment (S2) is very important. It can be seen that this is the development ranking. In addition, it is possible to derive an appropriate SWOT matrix development strategy through AHP result 1st tier priority analysis and AHP result 2nd tier priority analysis.

The following can be suggested as implications of this study.

In addition to the existing marina and cruise, there is a need for policies to foster industries that reflect recent trends such as underwater leisure, marine healing, and non-powered leisure sports (kayaks, canoes, paddle boats). Four strategies for revitalizing marine leisure sports are infrastructure (creating marine tourism sports attractions by region), content (reinforcement of experience and stay-oriented content), industry (cultivation of marine leisure sports core industry), culture (aquatic culture through education and experience).

A lot of effort is required to build a premium brand image of a differentiated company. For example, LG Electronics is doing various sponsorship sports marketing overseas. In addition, Hyundai Card is also making a lot of efforts, such as doing sports marketing. Now, it is necessary to create a premium corporate image by expanding from popular sports such as soccer and baseball to the leisure sports field. It is necessary to build a differentiated corporate image by investing in active leisure sports marketing and sponsorship of global companies.

As further implications of this study, this research proposes the development of virtual reality (VR) marine sports. In marine sports, the field of virtual reality using ITC as a new technology VR is important. In particular, it will create high demand for marine sports consumers in China and Asia including the Middle East. Especially, the Gulf countries in the Middle East such as Qatar, UAE, Saudi Arabia and Oman are mostly enjoying financial sanity as oil-producing country and trying to diversify the national industrial structure for the post oil era. The economic development plan 
leading by Saudi Arabia, 'Saudi Vision 2030' drives Tourism industry as one of the main parts and invests enormous project funds to NEOM City which is the special economic zone by the red sea.

The global COVID-19 pandemic situation and the development of the 4th industry would provide important momentum to change needs of consumer in the region. Marine sports activists can enjoy more realistic marine sports by performing $3 \mathrm{D}$ simulation through VR. The field of marine sports development using VR and AR (augmented reality) is still in its infancy. Therefore, it is necessary to search actively for virtual reality/augmented reality (VR/AR) content business areas and models in the field of marine sports. In addition, the consistent and continuous research on the strategic field using real marine sports and virtual marine sports is needed at this stage.

This study has various and important significances as described above, but has some limitations as follows, which are expected to be gradually supplemented in future studies. Above all, it is the subjective characteristic of the results shown through the SWOT/AHP model. The SWOT/AHP model, which was introduced to overcome the limitations of SWOT analysis, is also an expert, but it is necessary to be aware of interpreting these limitations somewhat because it is an evaluation method subject to the subjectivity of the evaluator. In addition, even if the consistency ratio (CR) is less than 0.1 in the AHP analysis process, it is difficult to overcome the relativity of the AHP model itself. Therefore, for more accurate analysis, various additional objective analysis models should be used. Lastly, in future research, we present a study to draw implications by comparing Korea's marine sports development strategy judged by Chinese experts with Korean expert groups.

\section{Reference}

Cho, G. T., Cho, Y. G., \& Kang, H. S. (2005). Hierarchical analytical decision making. Seoul: Donghyun Publishing Co.

Heung, J. R., Kim, W. S., \& Seo, D. H. (2009). The strategy for the human infrastructure construction of marine sports. Journal of Sport and Leisure Studies, 38(1), 87-97.

Ho, W. (2008). Integrated analytic hierarchy process and its applications: a literature review. European Journal of Operational Research, 186(1), 211-228.

Hwang, H. S. (2018). A study of the factors affecting leisure recognition and leisure use. Journal of the Korea Academia-Industrial cooperation Society, 19(2), 575-584.

Jeong, D. W., \& Hwang, S. S. (2008). Determinants of foreign direct investment of Korean companies using stratified analysis. Proceedings of the Korean Society for International Business Administration, 63-77.

Jin, Y., Park, J. S., \& Jung, J. S. (2020). A study on overseas case analysis and empirical analysis for the development of the hydrogen industry in Chungcheongbuk-do. International Business Review, 24(2), 77-90.

Kangas, J., Pesonen, M., Kurttila, M., \& Kajanus, M. (2001). Integrating the AHP with SWOT analysis. Proceeding of the 6th ISAHP, Berne, Switzerland (pp. 2-4). Retrieved July 18, 2020.

Kim, Y. J., \& Chung, J. C. (2012). The development strategy of Korean air logistics industry using SWOT-AHP method. Journal of Korea Trade, 37(4), 229-252.

Kurttila, M., Pesonen, M., Kangas, J., \& Kajanus, M. (2000). Utilizing the analytic hierarchy process (AHP) in SWOT analysis: A Hybrid Method and its Application to a Forest-certification Case. Forest Policy and Economics, 1(1), 41-52.

Lee, J. E. (2020). China's immovable, number of travelers and tourism spending No.1 in the world. Travel Times, 6 January, Section 3-4, Seoul, Korea.

Lee, J. H., Lee, J. M., Kim, J. H., \& Kim, H. G. (2017). A study on the perception change in marine sports by social media big data analysis. Korean Journal of Sport Management, 22(1), 31-46.

Lee, S. H. (2010). A study on the determinants of trade insurance utilization of small and medium-sized enterprises in Korea using AHP analysis. The 3rd University (Graduate) Student Thesis Contest Award.

Lee, S. H. (2012). A study on enhancements of international competitiveness of the Korean upstream energy companies. Busan, Korea: Thesis for Master in Pukyong National University.

Lim, K. H. (2019). A study on the present condition and strategy of marine sports industry of Korea. Korean Journal of Sport Management, 24(6), 80-92. 
Park, M. K., \& Kim, S. K. (2002). Research on the way of development in marine leisure-sports through the SWOT analysis. Korean Society for Sport Management, 7(1), 537-546,

Park, T. S. (2017). An analysis of the current state of marine sports through the analysis of social big data: Use of the social MaxtixTM method. Journal of fisheries and marine sciences education, 29(2), 593-606.

Park, Y. B. (2000). The Practical Using Program of the Sports Tour for the Improvement in the Local Community. Journal of Sport and Leisure Studies, 13(1), 687-698.

Rho, H. J., Rho, S. P., \& Kim, T. I. (1996). A study on the comprehensive evaluation model for government-funded research institutions. Journal of the Korean Policy Association, 5(1), 1996, 30-54.

Rui, D. G., Jung, Y. K., \& Lee, C. S. (2019). Marine (sea) familiarity index and its influence to national image. East Asian Journal of Business Economics, 7(3), 1-11.

Saaty, T. L. \& Kearns, K. P. (1985). Analytical Planning. Pergamon Press: New York.

Saaty, T. L. (1980). The analytic hierarchy process: planning, priority setting, resource allocation. New York: McGraw-Hill.

Seol, S. C., Song, M. S., \& Lee, J. S. (2011). Analysis of SWOT-AHP to strengthen brand competitiveness in Gyeongju tourism city. Journal of Korean Tourism and Leisure Association, 23(7), 25-42.

Travel News (2020.01.06). China- Chinese solo... No. 1 in the world for tourist destinations. Retrieved August 1, 2020, from https://www.traveltimes.co.kr/news/articleView.html?idxno=109071

Venrye (2019). Analysis of Marine Leisure Sports Market. Retrieved August 1, 2020, from https://m.blog.naver.com/ ben_rye/221628487762

Yonhap News (2019.08.22). marine leisure population surge... Not much to popularize at the level of advanced countries. Retrieved July 23, 2020, from https://www.yna.co.kr/view/AKR20190822079600051 